\title{
Study on the diagnosis of disturbed forest ecosystem in the Republic of Korea: in case of Daegwallyeong and Chupungryeong
}

\author{
Seon-Mi Lee ${ }^{*} \mathbb{D}$, Jae-Gyu Cha and Ho-Gyung Moon
}

\begin{abstract}
Background: Baekdudaegan was designated in 2005 as a protected area to prevent destruction and conserve. However, there are many disturbed and destroyed areas. The total disturbed area amounts to $25.9 \mathrm{~km}^{2}(0.94 \%)$, including $13.4 \mathrm{~km}^{2}(0.49 \%)$ in the core area and $12.5 \mathrm{~km}^{2}(0.45 \%)$ in the buffer area. This study aims to classify the vegetation types established in the disturbed areas and diagnose the current conditions for ecological restoration in the forest ecosystem.
\end{abstract}

Methods: We surveyed the vegetation in the disturbed areas of Daegwallyeong and Chupungryeong and the surrounding natural areas. The survey conducted from July to September 2015 targeted a total of 54 quadrats by Braun-Blanquet method (Daegwallyeong, 22; Chupungryeong, 32). We also investigated the height and coverage of each layer. We classified the vegetation types based on the field data and analyzed the ratio of life form and the exotic plants, species richness, and vegetation index ( $\mathrm{HCl}$ ). The Normalized Difference Vegetation Index (NDVI) was calculated from rapideye satellite imagery in 2014 and 2015.

Results: Vegetation types were classified into 11 groups according to the criteria that included successional sere or plantation at first, followed by developmental stage and origins. As a result of the analysis of the survey data, species richness, vegetation index $(\mathrm{HCl})$, ratio of tree plants, and the NDVI tended to increase, while the ratio of the exotic plants tended to decrease with the time since disturbance. These indicators had the classified values according to the vegetation types with time since the disturbance.

Conclusions: These indicators can be effectively used to diagnose the conditions of the present vegetation in the disturbed area of the Baekdudaegan area. In addition, the NDVI might be effective for the diagnosis of the disturbed status instead of the human efforts based on the higher spatial resolution of satellite imagery. Appropriate diagnosis of the disturbed forests in the Baekdudaegan area considering the established vegetation types is essential for the elaboration of restoration plans. In addition, restoration target and level should be different according to the disturbed status of restoration site.

Keywords: Baekdudaegan, Ecological restoration, Forest recovery, Vegetation succession, Successional stage, Diagnostic indicator, NDVI

\footnotetext{
* Correspondence: planteco@nie.re.kr

Division of Ecological Conservation, National Institute of Ecology, 1210

Geumgang-ro, Maseo-myeon, Seocheon-gun, Chungcheongnam-do 33657,

Republic of Korea
} 


\section{Background}

According to the Society for Ecological Restoration International Science \& Policy Working Group (2004), ecological restoration is practiced to assist the recovery of a degraded, damaged, or destroyed ecosystem, which is the most commonly used definition worldwide. For the successful ecological restoration, survey and analysis of a restoration site are essential. After the obvious diagnosis of the degraded site, it is possible to set up a clear target, goals, and objectives (Rieger et al. 2014).

Baekdudaegan refers to the mountain ranges linked from Mt. Baekdu in the Democratic People's Republic of Korea to Mt. Jiri in the Republic of Korea. This notion was firstly used by Doseon, a monk in the Goryeo dynasty. Afterwards, it was systematized and concretized through several documents, such as Taekriji by Jung Hwan Lee, Seonghosaseol by Ik Lee, and Sangyeongpyo by Gyeong Jun Shin in the Choseon dynasty (Lee and Kwon 2002).

The Baekdudaegan protected area was designated and notified by the Korea Forest Service in 2005 as one of the core ecological axes in the Republic of Korea. The purposes of designation are to prevent undiscerning destruction of the environment and conserve the natural environment (National Law Information Center 2015). It includes five provinces, six cities, and five counties. The total area increased from 263,427 ha in 2005 to 275,646 ha in 2016 (Korea Forest Service 2016). Baekdudaegan is one of the three main axes of Korean Peninsula along with the Demilitarized Zone (DMZ) and the coastal belt (AKECU 2010). It plays the important roles as biodiversity hotspots and ecological corridors of wildlife species (Korea Forest Service 2008).

In spite of the status of the protected area, there are many disturbed areas. The total damaged area amounts to $25.9 \mathrm{~km}^{2}(0.94 \%)$, including $13.4 \mathrm{~km}^{2}(0.49 \%)$ in the core area and $12.5 \mathrm{~km}^{2}(0.45 \%)$ in the buffer area (National Institute of Ecology 2015). Several studies addressed the damaged status (Cho 2012; Choi et al. 2014; Kwon and Lee 2003; Kwon et al. 2004; Lee et al. 2007a; Oh and Lee 2003) and restoration (Ahn et al. 2009; Daegu Gyeongbuk Development Institute 2008; Kim et al. 2008). These studies were mostly subjected to survey on the trial deterioration and studies on the diagnosis of the vegetation after disturbance or degradation are rare.

Several studies on the diagnosis using several indicators have been conducted in South Korea. For instance, Myung et al. (2002) diagnosed the stream vegetation through the diversity of plant community, exotic plant species, actual vegetation map, and vegetation profiles. Similarly, Kim (2009) developed the index consisting of vegetation diversity (the number of plant communities), ratio of exotic and annual plant species, vegetation profiles, and species richness (the number of plant species).
Furthermore, Nam (2015) studied species diversity, ratio of exotic plant and annual plant species, and vegetation. These studies were usually performed in the streams or rivers, but rarely addressed a forest ecosystem. Meanwhile, the first attempt to suggest a restoration practice according to the restoration level based on the damage degree from air pollution in South Korea was made by Kim et al. (2015) who selected vegetation types and damage degree as indicators.

This study aims to classify the vegetation types established in the disturbed areas and diagnose the current conditions for making use of ecological restoration after disturbances in the forest ecosystem.

\section{Methods}

\section{Study area}

From the time-series analysis by using the landuse maps in 2003 and 2013, we selected two study areas that were the most disturbed and destroyed (National Institute of Ecology 2015) (Fig. 1). One is Daegwallyeong in Pyeongchang county, Gangwon province (latitude N $37^{\circ} 42^{\prime} \sim \mathrm{N} 37^{\circ} 46^{\prime}$ and longitude E $128^{\circ} 40^{\prime} \sim \mathrm{E} 128^{\circ} 44^{\prime}$ ), and the other is Chupungryeong in Gimcheon city, Gyeongsangbuk province (latitude $\mathrm{N} 36^{\circ} 11^{\prime} \sim \mathrm{N} 36^{\circ}$ $12^{\prime}$ and longitude E $\left.127^{\circ} 59^{\prime} \sim \mathrm{E} 128^{\circ} 03^{\prime}\right)$. The mean annual precipitation and temperature during 30 years (1981 2010) were $1898.0 \mathrm{~mm}$ and $6.6{ }^{\circ} \mathrm{C}$ at Daegwallyeong Weather Station and $1187.1 \mathrm{~mm}$ and $11.7{ }^{\circ} \mathrm{C}$ at Chupungryeong Weather Station, respectively (Korea Meteorological Administration 2015). Daegwallyeong and Chupungryeong belong to the middle province as a floristic region and the cool temperate broad-leaved forest as a plant formation (Lee and Yim 1978).

\section{Disturbance characteristics}

Restoration attempts to return an ecosystem to the original state (Society for Ecological Restoration International Science \& Policy Working Group 2004) and the power of an ecosystem to do so is called resilience (Connell and Slatyer 1977; Greipsson 2011). Vegetation starts to recover naturally when the anthropogenic disturbances ceased or are neglected (Egler 1952). The main disturbance types were pastures in Daegwallyeong and fields in Chupungryeong (National Institute of Ecology 2015). In Daegwallyeong, Samyang pasture was developed from 1972 around 850 1400 $\mathrm{m}$ above the sea level (Noh et al. 2013). In addition, the wind power generators have been recently set up after the intact forests in this area were destroyed. Meanwhile, the main disturbance type was the fields in Chupungryeong (National Institute of Ecology 2015). Mostly, the fields that were far from the cities or difficult to access showed the tendency to be abandoned. Reduced agricultural activities resulted in forest recovery. 


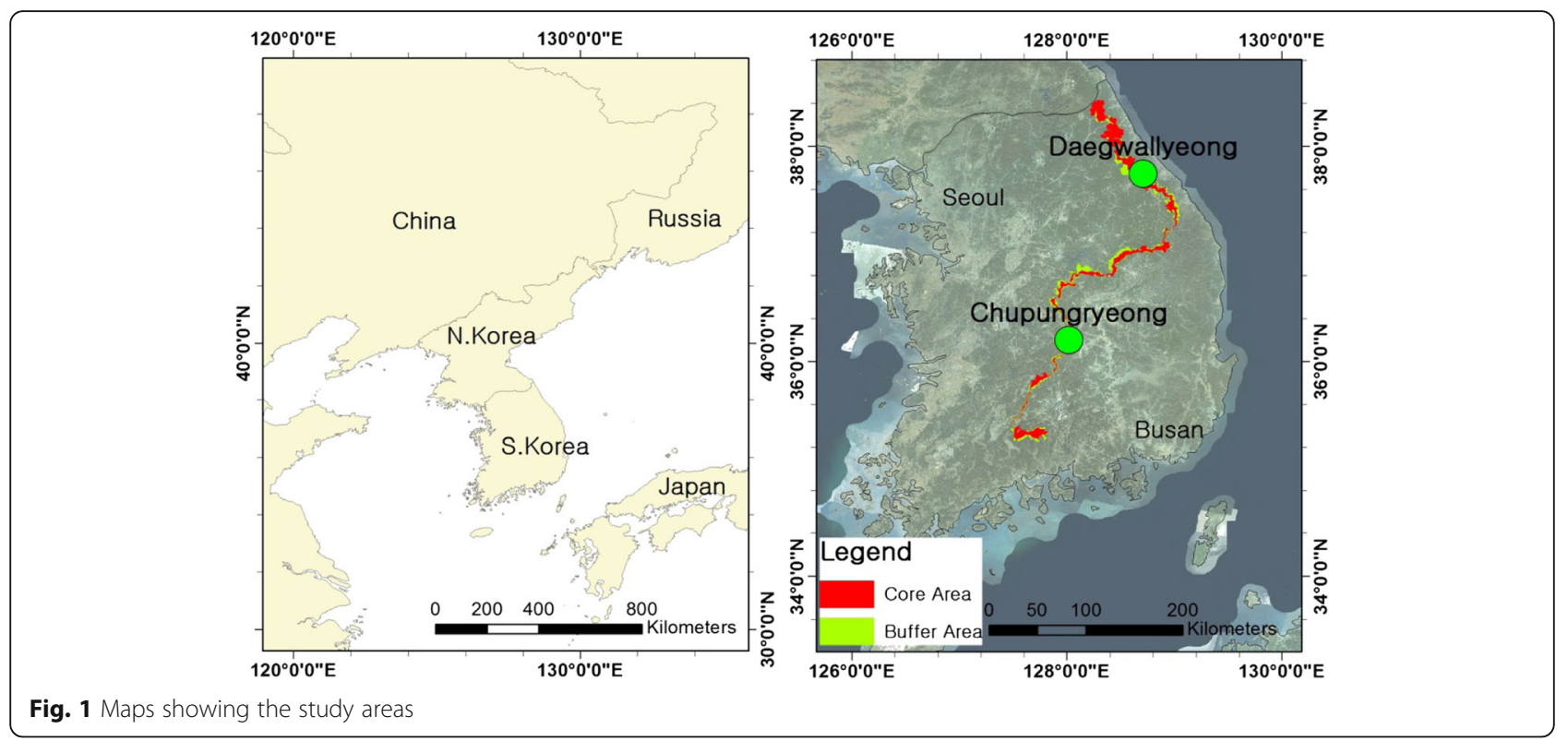

In this study, we surveyed the vegetation in the following five disturbance types that are abandoned or neglected: quarry, fields, paddy fields, and pastures, and plantations. We did not include the sites which are now in use after disturbances. In addition, the reason why we included the plantations is the positive effects of their ecological restoration reported in previous studies (Kim et al. 2013a; Lee et al. 2004a; Shin 2005).

\section{Vegetation survey}

We investigated the vegetation survey using the BraunBlanquet method (Braun-Blanquet 1964) in the disturbed area and surrounding natural area as a reference. The vegetation survey conducted from July to September 2015 targeted a total of 54 quadrats, including 22 quadrats in Daegwallyeong and 32 quadrats in Chupungryeong. The quadrant size was $2 \mathrm{~m} \times 2 \mathrm{~m}$ dominated by herbs, $5 \mathrm{~m} \times 5 \mathrm{~m}$ dominated by shrubs, and $10 \mathrm{~m} \times 10 \mathrm{~m}$ or $15 \mathrm{~m} \times 15 \mathrm{~m}$ dominated by trees. We also investigated the height and coverage of herb, shrub, subtree, and tree layers.

All plant species that appeared in each plot were identified by Lee (2014) and exotic plant species were identified by Park (2009) and Lee et al. (2011). Unidentified plants in the fields were collected and identified in the laboratory.

\section{Data analysis}

We divided the vegetation structure into the herb, shrub, subtree, and tree layers, which means the state of vegetation development. Then, the ratio of herbs, shrubs, and subtrees or trees was analyzed among the vegetation types. In addition, based on the surveyed data of the height and coverage of each layer, we calculated the vegetation index ( $\mathrm{Hcl}$ ) (formula 1) (Lee et al. 2004b). Additionally, we divided it by 100 .

$$
H c /=\sum(H / * V c l)(H l: \text { height of layer }(\mathrm{m}))
$$

The differences of vegetation index among vegetation types were tested with one-way ANOVA (SPSS, version 20.0).

\section{Satellite analysis}

To analyze the vegetation recovery according to vegetation types, Normalized Difference Vegetation Index (NDVI) was calculated from rapideye satellite imagery of Daegwallyeong in 2015 and Chupungryeong in 2014. NIR is the wavelength value of the near-infrared ray and RED is the wavelength value of the red visible ray.

$$
\mathrm{NDVI}=(\mathrm{NIR}-\mathrm{RED}) /(\mathrm{NIR}+\mathrm{RED})
$$

The value of NDVI ranged from -1 to 1 , theoretically. The areas not covered with vegetation have the value close to 0 . Meanwhile, the areas that are well developed with vegetation have the value close to 1 (Norman et al. 2014). Relative values to the highest value of the NDVI were compared.

\section{Results}

We categorized the vegetation types into 11 groups based on the field data. We made a division into three levels. Level 1 was mainly divided by successional sere including xerarch succession and hydrarch succession, plantation, and natural area as a reference. Level 2 was classified by developmental stages including herb, shrub, subtree, or tree according to the status of vegetation 
development. Level 3 was divided by origins of species such as exotic or indigenous characteristics (Table 1). Each type was expressed by remarks of Table 1 hereafter.

Rank-abundance curve according to the vegetation types is shown in Fig. 2. The number of species of the disturbed areas tended to increase with the lapse of time since abandonment or restoration practice such as plantation. The number of species in natural areas ranged from 44 to 84 . In addition, the number of species in P2 and $\mathrm{H} 3$ was almost similar to the corresponding number in the natural areas. The number of species in $\mathrm{X}$ types (X1, X2, and $\mathrm{X} 3$ ) was lower than that of $\mathrm{H}$ types $(\mathrm{H} 1$, $\mathrm{H} 2$, and $\mathrm{H} 3$ ).

Vegetation index $(\mathrm{Hcl})$, which was calculated by the mean coverage and height of tree, subtree, shrub, and herb layers, was high in the natural areas, and the values of P2 and $\mathrm{H} 3$ were similar to the corresponding values in the natural areas. However, the mean of P2 and H3 was still far from that of the natural area (see Fig. 4). A division of stratification through the value of mean and the distribution range of $\mathrm{Hcl}$ were clearly observed.

In the result of analysis on the growth form of plant species, percentages of tree species increased and those of herb species decreased with time since abandonment or restoration practice such as plantation. The percentage of tree species in $\mathrm{X} 3$ and $\mathrm{P} 2$ tended to be similar to that of $\mathrm{N}$ types $(\mathrm{N} 1, \mathrm{~N} 2$, and $\mathrm{N} 3$ ) than to other types. However, $\mathrm{H}$ types $(\mathrm{H} 1, \mathrm{H} 2$, and $\mathrm{H} 3$ ) did not obviously show that tendency (Fig. 3). By contrast, the ratio of exotic plants was high in X1 and P1 and decreased with time since abandonment or plantation. On the other hand, ratio of exotic plant species emerged in $\mathrm{H} 3$ (Fig. 5).

NDVI of each type, extracted from rapideye satellite imagery, is shown in Fig. 6. As the result of comparison,

Table 1 Categorization of the vegetation types into 11 groups based on the field data

\begin{tabular}{|c|c|c|c|c|}
\hline Level 1 & Level 2 & Level 3 & Remark & No. of plots \\
\hline \multirow{3}{*}{$\begin{array}{l}\text { Xerarch } \\
\text { succession }\end{array}$} & \multirow[t]{2}{*}{ Herb } & Exotic & $\mathrm{X} 1$ & 14 \\
\hline & & Indigenous & $x 2$ & 6 \\
\hline & Shrub & Indigenous & X3 & 4 \\
\hline \multirow{3}{*}{$\begin{array}{l}\text { Hydrarch } \\
\text { succession }\end{array}$} & Herb & Indigenous & $\mathrm{H} 1$ & 3 \\
\hline & Shrub & Indigenous & $\mathrm{H} 2$ & 3 \\
\hline & Subtree/Tree & Indigenous & $\mathrm{H} 3$ & 3 \\
\hline \multirow[t]{2}{*}{ Plantation } & Shrub & Exotic/indigenous & P1 & 3 \\
\hline & Subtree/Tree & Exotic/indigenous & P2 & 4 \\
\hline \multirow[t]{3}{*}{ Natural area } & \multirow[t]{3}{*}{ Tree } & $\begin{array}{l}\text { Indigenous } \\
\text { (Quercusmongolica) }\end{array}$ & N1 & 9 \\
\hline & & $\begin{array}{l}\text { Indigenous } \\
\text { (Q. serrata) }\end{array}$ & N2 & 3 \\
\hline & & $\begin{array}{l}\text { Indigenous } \\
\text { (Q. acutissima) }\end{array}$ & N3 & 3 \\
\hline
\end{tabular}

it also increased with time since abandonment or plantation. The value of $\mathrm{P} 2$ and $\mathrm{H} 3$ types tended to be similar to $\mathrm{N}$ types (N1, N2, and N3). However, standard deviation showed a high value. As a result of one-way ANOVA test, there are significant differences at the 0.001 level among vegetation types (see Table 2 ).

\section{Discussion}

An ecological restoration project involves several developmental processes, such as planning, design, implementation, and aftercare. Each step includes major actions, such as an initiate project, site analysis, SWOT-C, refined goals and objectives, project scope, concept design, project plans, installation, monitoring, remediation, project close-out, and projects added to the ongoing program (Rieger et al. 2014). It is a costeffective way based on the site analysis and diagnosis evaluation to improve restoration effects (Lee et al. 2005; Lee et al. 2007b).

Vegetation can be easily surveyed to provide valuable information about disturbances and environmental processes (Amoros et al. 2000). In the present study, we classified the vegetation types for making use of restoration practice in the forest ecosystem. We analyzed five indicators related to vegetation development to diagnose the disturbed forest ecosystem in Daegwallyeong and Chupungryeong, namely, species richness; vegetation index $(\mathrm{Hcl})$; the ratio of the exotic species and that of the herb, shrub, and tree species; and NDVI. These indicators were used in numerous studies related to forest recovery after disturbance. Specifically, species richness (namely, the number of species) was used by Kim et al. (2013a, b), Lee et al. (2002), Lee (2006), and Lindborg and Eriksson (2004); vegetation index was employed by Lee et al. (2004b) and Lee (2006); the ratio of exotic species was used by Kim et al. (2013b); the ratio of annual herbs or tree species was employed by Burt and Rice (2009), Grime (2001), and Lee (2006). Finally, Cai et al. (2015), Leon et al. (2012), and van Leeuwen (2008) used NDVI. Sizeable differences in the most indicators were observed between $\mathrm{X} 1$ and $\mathrm{N}$ types (N1, N2, and N3). In addition, our results confirmed that most indicators of $\mathrm{H} 3$ and P2 have similar conditions to those of $\mathrm{N}$ types as references (see Figs. 2, 3, 4, 5 and 6). However, the ratio of the exotic plants in H3 was exceptional. Generally, exotic species disappear when trees make a crown and provide a shade (Korea National Park Research Institute 2014). Although Salix koreensis, which is the dominant plant in H3, developed to the tree layer and made a shade, the ratio of exotic species emerged, while $\mathrm{H} 1$ and H2 did not (see Fig. 5). Exotic species that invaded in H3 were just two: Erigeron annuas and Bidens frondosa. It was assumed that E. annuas was invaded temporarily from the surrounding areas according to the decrease of 


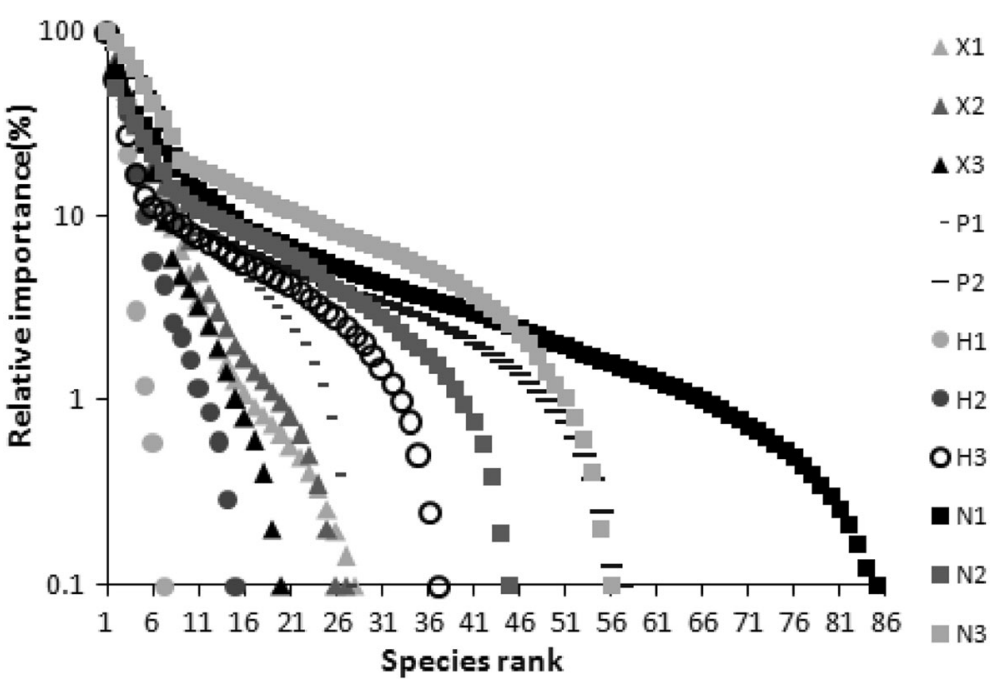

Fig. 2 Rank-abundance curve obtained from the vegetation data according to the vegetation types

soil water contents since the time after abandonment. In addition, we assumed that $B$. frondosa was a remnant from the early stage of abandoned paddy fields. Many previous studies reported that $B$. frondosa showed up or was dominant in paddy fields in South Korea (Lee 1997; Kim et al. 2011). However, B. frondosa has heliophilous seeds (Shin et al. 1999). They might disappear when the vegetation development go on and make a shade more densely. Meanwhile, the ratio of exotic species in N1, N2, and N3 types showed up slightly. Exotic plants that were entered into the intact natural forests were mainly Robinia pseudoacacia and Larix kaempferi which are the major afforestation tree species in South Korea. We found only very few of them in the intact natural forests. It is supposed that these exotic plants invaded from the surrounding plantations.
Meanwhile, the vegetation index $(\mathrm{Hcl})$ was developed to estimate the vegetation developmental processes in the area severely disturbed by fire. It well explained the development of vegetation stratification. It was proved that the vegetation index showed a high correlation with the time since fire disturbance (Lee et al. 2004b). Processes and speed of the vegetation development after disturbance might vary according to the disturbance types and location conditions. However, most disturbed areas are under the vegetation development immediately after the disturbances ceased (Egler 1952). Therefore, the vegetation index is an effective indicator for confirming the vegetation developmental processes, as it is calculated by the height and coverage of each layer. We confirmed that the vegetation index showed the low values in the early developmental stage with herb layers

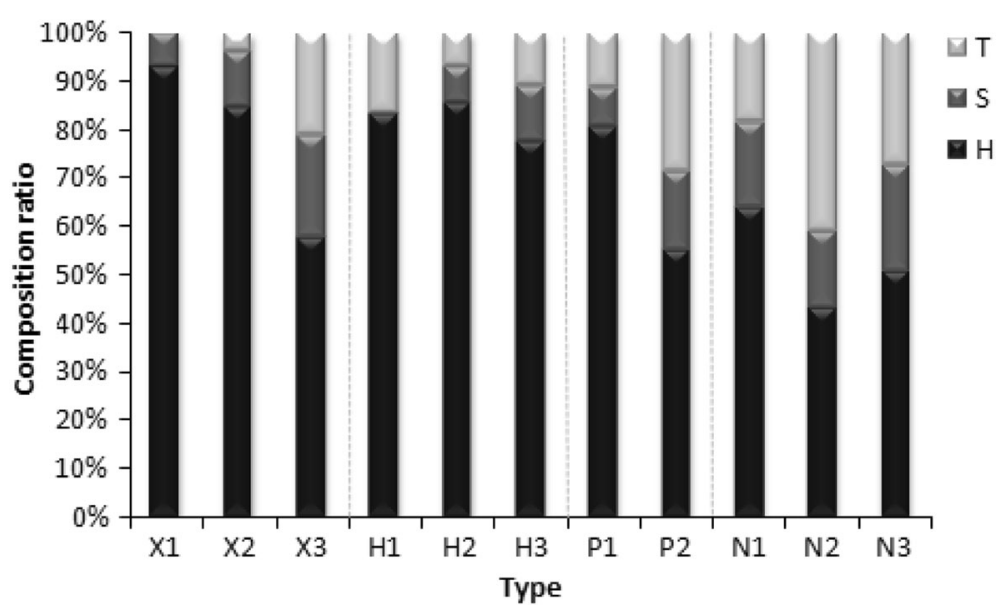

Fig. 3 Comparison of the composition ratio by growth form of plant species according to the vegetation types. $H$ herb, $S$ shrub, $T$ tree) 
Table 2 Results of one-way ANOVA for vegetation index calculated from the vegetation coverage and height

\begin{tabular}{llrlll}
\hline Vegetation types & $N$ & Mean & Std & $F$ & $p$ \\
\hline X1 & 14 & 1.1 & 0.6 & 37.102 & $0.000^{*}$ \\
X2 & 6 & 1.3 & 0.3 & & \\
H1 & 4 & 0.8 & 0.1 & & \\
H2 & 3 & 1.0 & 0.1 & & \\
H3 & 3 & 3.3 & 1.5 & & \\
P1 & 3 & 11.7 & 1.0 & & \\
P2 & 3 & 2.6 & 0.2 & & \\
N1 & 4 & 11.7 & 7.3 & & \\
N2 & 9 & 14.3 & 3.1 & & \\
N3 & 3 & 14.2 & 1.0 & & \\
${ }^{*} p<0.001$ & 3 & 18.0 & 1.8 & &
\end{tabular}

(X1, X2, and $\mathrm{H} 1$ ) ranging from 0.5 to 2.1. That of the later developmental stage with subtree or tree layers (H3 and P2) showed higher values ranging from 5.6 to 22.3. These results are similar trend with those reported by Lee et al. (2004b). Therefore, studies on the quantification of the vegetation index and analyzing its correlation with the time since disturbance are needed in the future.

The NDVI has been shown to be the most effective index to quickly and simply identify the vegetated area and its condition (Agone and Bhamare 2012). It has been widely used to monitor vegetation (Benedetti and Rossini 1993; Kinyanjui 2011; Meneses-Tovar 2011; Wessels 2005) and to find the historical information of vegetation cover changes (Peters et al. 2002). Very low values of NDVI ( 0.1 and below) were observed in the barren areas, such as rocks, sand, or snow, while moderate values ( 0.2 to 0.3$)$ were observed in shrub and grassland areas. In addition, high values (0.6 to 0.8$)$ correspond to temperate and tropical rain forests (Weier and Herring 2000). Therefore, there is a correlation between vegetation types and various sites (MenesesTovar 2011). In fact, field survey is the most accurate way to identify the disturbed status. However, it is difficult to cover broad areas, because this approach is time-consuming, expensive, and requires more people who can conduct the field survey (Alshaikh 2015). In an attempt to make use of the NDVI for the diagnosis, in the present study, we tried to diagnose the disturbed status by comparing the values of NDVI calculated from rapideye satellite imagery. Our results confirmed the effect of NDVI. Specifically, H3, P2, N1, N2, and N3 which are types dominated by the tree or subtree layer had higher values than other types. However, the difference between herb dominated types (X1, X2, and $\mathrm{H} 1$ ) and shrub dominated types (X3, H2, and P1) was not significant (see Fig. 6). It can be inferred that the damaged area sampled from the field was narrow and the spatial resolution of rapideye satellite imagery is low to detect spatial variability (Wessels 2005). Therefore, in further research, a higher spatial resolution of satellite imagery is necessary and the number of samples should be sufficient. In addition, the NDVI from the low resolution of satellite imagery is suitable for a broadly degraded area.

The indicators suggested in the present study are broadly applicable for other disturbed areas, including many disturbance types in a forest ecosystem. However,

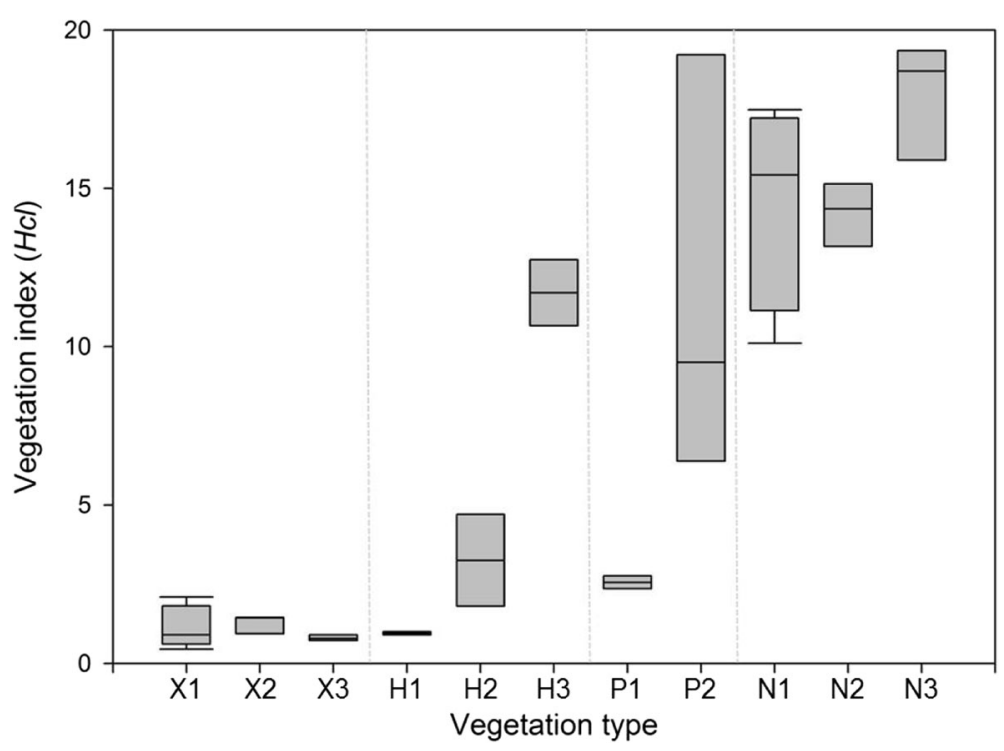

Fig. 4 Comparisons of vegetation index $(\mathrm{HCl})$ according to the vegetation types 


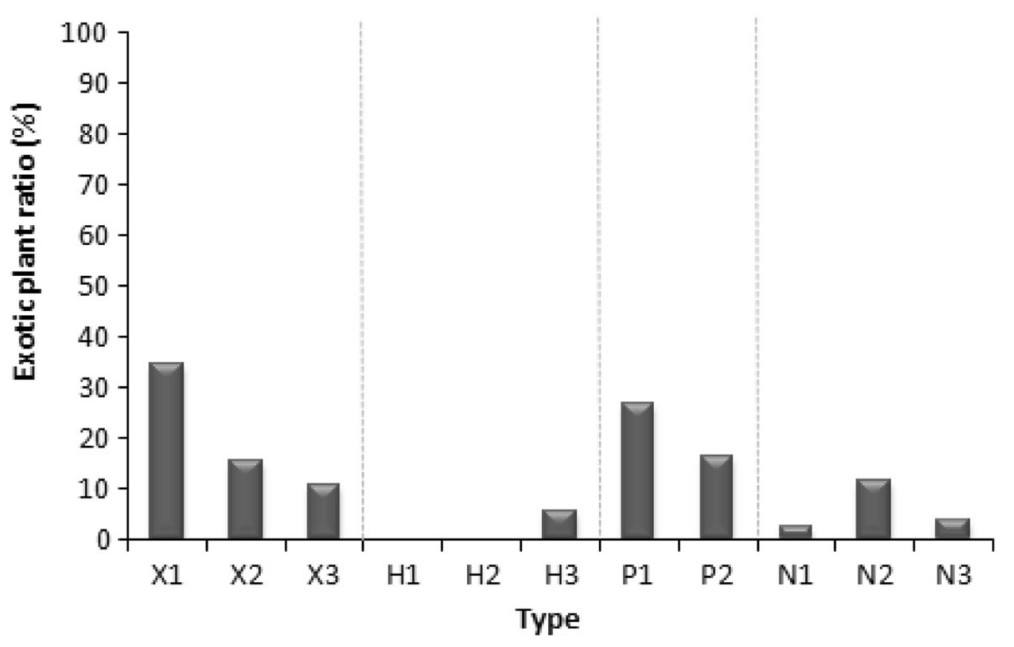

Fig. 5 The ratio of exotic plants to the total number of species of the each vegetation type

specific indicators for the each disturbance type should be chosen. In addition, a more precise survey should be practiced for a restoration project of a specific area. For a successful restoration, a restoration plan based on the accurate survey and diagnosis of the degraded area in the Baekdudaegan has to be proposed. In addition, restoration target and level should be different according to the disturbed status of restoration site.

\section{Conclusions}

An ecological restoration project involves several developmental processes, such as planning, design, implementation, and aftercare. Diagnosis evaluation of degraded forest considering the established vegetation types is essential for the elaboration of restoration plans. In the present study, we classified the vegetation types according to the developmental stages, species composition, and characteristics of dominant species. Species richness, vegetation index $(\mathrm{Hcl})$, the ratio of tree plants, and NDVI tended to increase, but the ratio of exotic plants tended to decrease with the time since abandonment. In addition, we confirmed a correlation between vegetation types and the values of the NDVI. Therefore, we suggested the five indicators for diagnosis. These indicators are applicable for broadly degraded areas, including many disturbance types in a forest ecosystem. However, specific indicators for each disturbance type should be chosen. In addition, a more precise survey should be practiced for a restoration project of a specific area. A restoration plan based on the correct diagnosis of the degraded area in the Baekdudaegan area has to be proposed for successful restoration.

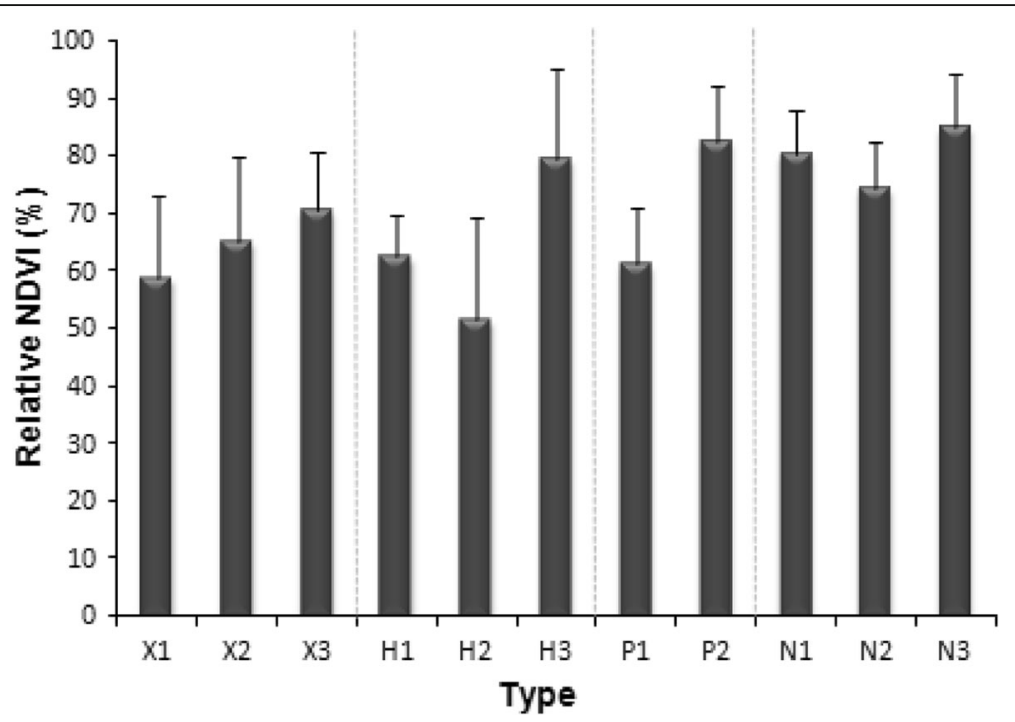

Fig. 6 Relative NDVIs according to the vegetation types from the rapideye satellite imagery 


\section{Acknowledgements}

We sincerely appreciated Hyeon Ho and Myeong from the Korea National Park Research Institute for reviewing willingly this manuscript.

\section{Funding}

This study was supported by the National Institute of Ecology titled "Conservation and Restoration Based Research on the Core Ecological Axis of the Korean Peninsula" in 2015.

\section{Availability of data and materials}

The data will not be shared for a reason.

\section{Authors' contributions}

SML carried out the field survey and data analysis and drafted the manuscript. JGC analyzed the NDVI from the rapideye satellite imagery. HGM supported the field survey and entered the data into a computer. All authors read and approved the final manuscript.

\section{Competing interests}

The authors declare that they have no competing interests.

\section{Consent for publication}

Not applicable.

\section{Ethics approval and consent to participate}

Not applicable.

\section{Publisher's Note}

Springer Nature remains neutral with regard to jurisdictional claims in published maps and institutional affiliations.

Received: 27 October 2016 Accepted: 11 June 2017

Published online: 12 July 2017

\section{References}

Agone, V., \& Bhamare, S. M. (2012). Change detection of vegetation cover using remote sensing and GIS. Journal of Research and Development, 2, 1-12.

Ahn, T. M., Kim, I. H., Lee, J. Y., Kim, C. K., Chae, H. S., Lee, Y., Min, S. Y., \& Kim, M. W. (2009). Development of participatory ecological restoration system through integrative categorization of disturbed areas in BaigDooDaeGahn. The Korea Society for Environmental Restoration and Revegetation Technology, 12, 11-22 (in Korean with English abstract).

AKECU (ASEAN-Korea Environmental Cooperation Unit). (2010). Biodiversity and natural resources conservation in protected areas of Korea and the Philippines (p. 31). Seoul: GeoBook

Alshaikh, A. Y. (2015). Space applications for drought assessment in Wadi-Dama (West Tabouk), KSA. Egyptial Journal of Remote Sensing \& Space Sciences, 18, 43-53.

Amoros, C., Bornette, G., \& Henry, C. P. (2000). A vegetation-based method for ecological diagnosis of riverine wetlands. Environmental Management, 25, 211-227.

Benedetti, R., \& Rossini, P. (1993). On the use of NDVI profiles as a tool for agricultural statistics: the case study of wheat yield estimate and forecast in Emilia Romagna. Remote Sensing of Environment, 45, 311-326.

Braun-Blanquet, J. (1964). Pflanzensoziologie (p. 865). Wien: Grundzuge der Vegetationstunde

Burt, J. W., \& Rice, K. J. (2009). Not all ski slopes are created equal: disturbance intensity affects ecosystem properties. Ecological Applications, 19, 2242-2253.

Cai, H., Yang, X., \& Xu, X. (2015). Human-induced grassland degradation/ restoration in the central Tibetan Plateau: the effects of ecological protection and restoration projects. Ecological Engineering, 83, 112-119.

Cho, W. (2012). Deterioration status of closed-trail of national parks on the Baekdudaegan mountains, South Korea. Korean Journal of Environment and Ecology, 26, 827-834 (in Korean with English abstract).

Choi, S. M., Kweon, H. K., Lee, J. W., Choi, Y. H., \& Choi, T. J. (2014). A study on deterioration of ridge trail in Jeongmaek. Korean Journal of Environment and Ecology, 28, 450-456 (in Korean with English abstract).

Connell, J. M., \& Slatyer, R. O. (1977). Mechanisms of succession in natural communities and their role in community stability and organization. American Naturalist, 111, 1119-1144.
Daegu Gyeongbuk Development Institute. (2008). Research on the ecological restoration plan of Ihwaryeongin the Baekdudaegan (p. 37) (in Korean).

Egler, F. E. (1952). Vegetation science concepts I. Initial floristic composition, a factor in old-field vegetation development with 2 figs. Vegetatio, 4, 412-417.

Greipsson, S. (2011). Restoration ecology (pp. 104-105). Canada: Jones \& Bartlett Learning, LLC.

Grime, J. P. (2001). Plant strategies and vegetation processes (2nd ed.). Chichester: Wiley.

Kim, H. S. (2009). Diagnostic evaluation on the Korea rivers for restoration of vegetation (Master's degree of Seoul Women's University, p. 61) (in Korean with English abstract)

Kim, N. C., Nam, U. J., \& Shin, K. J. (2008). A study on the slope ecological restoration models for the Baekdu-mountain range. The Korea Society for Environmental Restoration and Revegetation Technology, 11, 72-84 (in Korean with English abstract)

Kim, S. K., Kim, S. Y., Won, J. G., Shin, J. H., \& Kwon, O. D. (2011). Prediction of rice yield loss and economic threshold level by densities of Sagittaria trifolia and Bidens frondosa in direct-seeding flooded rice. Korean Journal of Weed Science, 31, 340-347 (in Korean with English abstract).

Kim, S. M., An, J. H., Lim, Y. K., Pee, J. H., Kim, G. S., Lee, H. Y., Cho, Y. C., Bae, K. H., \& Lee, C. S. (2013a). Ecological changes of the Larix kaempferi plantations and the restoration effects confirmed from the results. Korean Journal of Ecology and Environment, 46, 241-250 (in Korean with English abstract).

Kim, S. M., An, J. H., Lim, Y. K., Pee, J. H., Kim, G. S., Lee, H. Y., Cho, Y. C., Bae, K. H., \& Lee, C. S. (2013b). The effects of ecological restoration confirmed in the Pinus koraiensis plantation. Journal of Agriculture \& Life Science, 47, 19-28 (in Korean with English abstract).

Kim, G. S., Pee, J. H. An, J. H., Lim, C. H., \& Lee, C. S. (2015). Selection of air pollution tolerant plants through the 20-years-log transplanting experiment in the Yeocheon industrial area, southern Korea. Animal Cells and Systems, 19 208-215.

Kinyanjui, M. J. (2011). NDVI-based vegetation monitoring in Mau forest complex Kenya. African Journal of Ecology, 49, 165-174

Korea Forest Service. (2008). Forest policy white book (p. 334) (in Korean).

Korea Forest Service. (2016). Notification of area extension of Beakdudaegan protected area (in Korean).

Korea Meteorological Administration. (2015). http://www.kma.go.kr (in Korean) (26 Dec 2015 accessed).

Korea National Park Research Institute. (2014). Study on the management plan of specific exotic species-exotic plants (p. 142) (in Korean).

Kwon, T. H., \& Lee, J. W. (2003). Trail deterioration on the ridge of the Baekdudaegan - a case of the trail between Manbokdae and Bokseongijae. Korean Journal of Environment and Ecology, 16, 465-474 (in Korean with English abstract).

Kwon, T. H., Lee, J. W., \& Kim, D. W. (2004). Trial deterioration and managerial strategy on the ridge of the Baekdudaegan: a case of the trial between Namdeogyusan and Sosagogae. Korean Journal of Environment and Ecology, 18, 175-183 (in Korean with English abstract)

Lee, H. S. (1997). Studies on germination characteristics of Bidens tripartite and Bidens frondosa (Master's thesis of Kyunghee University, p. 25) (in Korean with English summary).

Lee, K. S. (2006). Changes of species diversity and development of vegetation structure during abandoned field succession after shifting cultivation in Korea. Journal of Ecology and Field Biology, 29, 227-235 (in Korean with English abstract).

Lee, T. B. (2014). Illustrated flora of Korea (p. 1828). Seoul: Hyangmunsa (in Korean).

Lee, J. W., \& Kwon, T. H. (2002). Present states and management proposal of the Baekdudaegan-area in Doraegijae Pijae. Korean Journal of Environmental Ecology, 15, 420-430 (in Korean with English abstract).

Lee, W. T., \& Yim, Y. J. (1978). Studies on the distribution of vascular plants in the Korea peninsula. Korean Journal of Plant Taxonomy, 8(Supplement), 1-33 (in Korean with English abstract).

Lee, C. S., You, Y. H., \& Robinson, G. R. (2002). Secondary succession and natural habitat restoration in abandoned rice fields of central Korea. Restoration Ecology, 10, 306-314.

Lee, C. S., Cho, H. J., \& Yi, H. B. (2004). Stand dynamics of introduced black locust (Robinia pseudoacacia L.) plantation under different disturbance regimes in Korea. Forest Ecology and Management, 189, 281-293.

Lee, K. S., Choung, Y. S, Kim, S. C. Shin, S. S., Ro, C. H. \& Park, S. D. (2004). Development of vegetation structure after forest fire in the east coasta region, Korea. Korean Journal of Ecology, 27, 99-106 (in Korean with English abstract). 
Lee, C. S., Cho, Y. C., Shin, H. C., Moon, J. S., Lee, B. C., Bae, Y. S., Byun, H. G., \& Yi, H. (2005). Ecological response of streams in Korea under different management regimes. Water Engineering Research, 6, 131-147.

Lee, C. S., Cho, Y. C., Shin, H. C., Lee, S. M., \& Cho, H. J. (2007). Effect of partial habitat restoration by a method suitable for riverine environments in Korea. Journal of Ecology and Field Biology, 30, 171-177.

Lee, D. K., Song, W. K., Jeon, S. W., Sung, H. C., \& Son, D. Y. (2007). Deforestation patterns analysis of the Baekdudaegan Mountain Range. The Korea Society for Environmental Restoration and Revegetation Technology, 10, 41-53 (in Korean with English abstract).

Lee, Y. M., Park, S. H., Jung, S. Y., Oh, S. H., \& Yang, J. C. (2011). Study on the current status of naturalized plants in South Korea. Korean Journal of Plant Taxonomy, 41, 87-101. in Korean with English abstract.

Leon, J. R. R., van Leeuwen, W. J. D., \& Casady, G. M. (2012). Using MODIS-NDVI for the modeling of post-wildfire vegetation response as a function of environmental conditions and pre-fire restoration treatments. Remote Sensing, 4, 598-621.

Lindborg, R., \& Eriksson, O. (2004). Effects of restoration on plant species richness and composition in Scandinavian semi-natural grasslands. Restoration Ecology, 12, 318-326.

Meneses-Tovar, C. L. (2011). NDVI as indicators of degradation. Unasylva, 238, 39-46.

Myung, H., Kwon, S. Z., \& Kim, C. H. (2002). Diagnosis of vegetation for the ecological rehabilitation of streams-the case of the Namhanriver. Journal of Korean Institute of Landscape Architecture, 30, 98-106 (in Korean with English abstract).

Nam, G. B. (2015). Diagnostic evaluation about Han river basin and restoration planning based on its evaluation (Master's degree of Seoul Women's University, p. 83) (in Korean with English abstract).

National Institute of Ecology. (2015). Conservation and restoration based research on the core ecological axis of the Korean peninsula (in Korean with English abstract).

National Law Information Center. (2015). http://www.law.go.kr/lsSc.do?menuld= $0 \& p 1=\&$ subMenu $=1 \& n w Y n=1 \&$ section $=\&$ tabNo $=\& q u e r y=\% E B \% B 0 \% B 1 \%$ EB\%91\%90\%EB\%8C\%80\%EA\%B0\%84\%20\%EB\%B3\%B4\%ED\%98\%B8\%EC\%97\% 90\%20\%EA\%B4\%80\%ED\%95\%9C\%20\%EB\%B2\%95\%EB\%A5\%A0\#undefined (in Korean) (26 Dec 2015 accessed).

Noh, T. H., Han, B. H., Kim, J. Y., Lee, M. Y., \& Yoo, K. J. (2013). Actual vegetation and structure of plant community in Daegwallyeong ranch, Gangwon-do (Province). Korean Journal of Environment and Ecology, 27, 579-591 (in Korean with English abstract).

Norman, L., Villarreal, M., Pulliam, H. R., Minckley, R., Gass, L., Tolle, C., \& Coe, M. (2014). Remote sensing analysis of riparian vegetation response to desert marsh restoration in the Mexican Highlands. Ecological Engineering, 70, 241-254.

Oh, K. K., \& Lee, J. E. (2003). Literatures review for the flora, vegetation and environmental management in the Baekdudaegan - from Cheonwangbong in the Jirisan to Hyangjeokbong in the Deokyusan. Korean Journal of Environment and Ecology, 16, 475-486 (in Korean with English abstract).

Park, S. H. (2009). Colored illustration of naturalized plants of Korea (p. 602). Seoul: Ilchokak (in Korean).

Peters, A. J., Walter-Shea, E. A., Ji, L., Viña, A., Hayes, M., \& Svoboda, M. D. (2002). Drought monitoring with NDVI-based standardized vegetation index. Photogrammetric Engineering \& Remote Sensing, 68, 71-75.

Rieger, J., Stanley, J., \& Traynor, R. (2014). Project planning and management for ecological restoration (pp. 7-11). Washiington: Island Press.

Shin, H. C. (2005). The effects of ecological restoration confirmed in the Pitch pine (Pinus rigida) plantation (Master's degree of the Seoul Women's University, Seoul, Korea, p. 42) (in Korean with English abstract).

Shin, H. J., Shin, J. S., Kim, J. H., Kim, H. Y., Lee, I. J., Shin, D. H., \& Kim, K. U. (1999). Study on seed germination of Bidens tripartite $\mathrm{L}$. and Bidens frondosa $\mathrm{L}$. Agricultural Research Bulletin of Kyungpook National University, 17, 53-57 (in Korean with English abstract).

Society for Ecological Restoration International Science \& Policy Working Group. (2004). The SER international primer on ecological restoration. Tucson: Society for Ecological Restoration International. www.ser.org.

Van Leeuwen, W. J. D. (2008). Monitoring the effects of forest restoration treatments on post-fire vegetation recovery with MODIS multitemporal data. Sensors, 8, 2017-2042.

Weier, W., \& Herring, D. (2000). Measuring vegetation (NDVI\&EVI). http:// earthobservatory.nasa.gov/Features/MeasuringVegetation/.

Wessels, K. J. (2005). Monitoring land degradation in southern Africa by assessing changes in primary productivity (Ph.D. Dissertation of the University of Maryland, p. 146).

\section{Submit your next manuscript to BioMed Central and we will help you at every step:}

- We accept pre-submission inquiries

- Our selector tool helps you to find the most relevant journal

- We provide round the clock customer support

- Convenient online submission

- Thorough peer review

- Inclusion in PubMed and all major indexing services

- Maximum visibility for your research

Submit your manuscript at www.biomedcentral.com/submit 